\title{
ANTIBACTERIAL ACTIVITY OF KARAMUNTING (RHODOMYRTUS TOMENTOSA (AITON) HASSK) LEAF EXTRACT AND FRACTIONS
}

\author{
SISKA ESPERANZA SINULINGGA ${ }^{1 *}$, POPPY ANJELISA ZAITUN HASIBUAN ${ }^{1}$, DWI SURYANTO ${ }^{2}$ \\ ${ }^{1}$ Department of Pharmacology, Faculty of Pharmacy, University of Sumatera Utara, Medan, Indonesia. ${ }^{2}$ Department of Biology, Faculty of \\ Mathematics and Natural Sciences, University of Sumatera Utara, Medan, Indonesia. Email: Siskaesperanza@gmail.com
}

Received: 06 November 2017, Revised and Accepted: 01 December 2017

\section{ABSTRACT}

Objective: This study was to analyze the karamunting leaf extract and fractions effectiveness against Staphylococcus aureus and Pseudomonas aeruginosa infection.

Methods: Phytochemical screening is done in the extract and fractions of karamunting leaf continue with Standard agar well diffusion method for $S$. aureus and P. aeruginosa. Dimethyl sulfoxide was used as negative control, and standard antibiotic Kalmicetine (chloramphenicol) was used as positive control.

Result: The ethyl acetate fraction showed the highest antibacterial activity against S. aureus and P. aeruginosa.

Conclusion: Karamunting leaf can be used to treat the bacterial infection diseases especially infection from S. aureus and P. aeruginosa.

Keywords: Antibacterial, Extract, Fraction, Karamunting, Staphylococcus aureus and Pseudomonas aeruginosa.

(c) 2018 The Authors. Published by Innovare Academic Sciences Pvt Ltd. This is an open access article under the CC BY license (http://creativecommons. org/licenses/by/4. 0/) DOI: http://dx.doi.org/10.22159/ajpcr.2018.v11i3.23505

\section{INTRODUCTION}

It is believed that the history of humankind medicine treatment already using herbal medicine to treat with many diseases. Some of the advantages of herbal medicines are that they have fewer side effects and safe to use over time. They also inexpensive compared to the formulated drugs and they are readily available [1]. One of the common diseases is an infection from microbial. Recently, the antibiotic drugs mostly have been resistance and become an increasingly serious problem [2] and this case, making the development of alternative antibiotics a very urgent issue.

Medicinal plants have been studied extensively as alternative antimicrobial therapeutic agents [3]. One of the rising plants is Karamunting (Rhodomyrtus tomentosa [Aiton] Hassk). Karamunting has been used in traditional Vietnamese, Chinese and Malaysian medicine to treat diarrhea [4]. Karamunting are known to be effective in antibiofilm, antibacterial, antifungal, antioxidant, antidiarrheal, osteogenic, and anti-inflammatory [5-10]. The woods of karamunting are employed to cure wounds and injuries [11].

The purpose of this study was to explore leaf of karamunting for possible antibacterial activity, especially on Staphylococcus aureus and Pseudomonas aeruginosa in skin infection. Ethanolic extract of the leaf of the plant and its fractions in different solvents were tested against S. aureus and P. aeruginosa.

\section{METHODS}

\section{Sample collection}

Fresh leaf samples of Karamunting ( $R$. tomentosa (Aiton) Hassk) were collected from Sipoholon district, North Sumatera, Indonesia, in the month of July 2016. The collected samples were brought to the laboratory on the same day and authenticated by the Indonesian Institute of Sciences: Research Center for Biology (Code: 1581/ IPH.1.01/If.07/VII/2016). The dried leaf samples were crushed and ground to obtain a finely divided powder.
Extraction and fractionation

Ethanolic extract of the powder was obtained by the maceration method for 7 days followed by filtration. The ethanolic solvent was evaporated on a rotary evaporator to obtain crude ethanolic extract and dried using freeze dryer to get the dried crude ethanolic extract. The ethanolic extract was then suspended in distilled water and partitioned with hexane and ethyl acetate to obtain fractions of these solvents. The solvents were removed on a rotary evaporator to obtain dried fractions $[11,12]$.

\section{Preliminary phytochemical screening}

Phytochemical screening carried out on ethanolic extract, hexane fraction, and ethyl acetate fraction includes examining the chemical secondary metabolites of alkaloids, flavonoids, glycosides, saponins, tannins, triterpenoids, and steroids [13-16].

\section{Antibacterial activity}

Microorganisms used

The bacteria used are Gram-positive bacteria (Staphylococcus aureus/ ATCC 6538) and Gram-negative bacteria (P. aeruginosa/ATCC 9027) which were obtained from Microbiology Laboratory, Faculty of Pharmacy, University of Sumatera Utara, with each concentration of culture test was $10^{6} \mathrm{cfu} / \mathrm{ml}$ which has been likened to the turbidity standard solution of Mac Farland.

\section{Agar well diffusion method}

Antibacterial activity was tested by the agar well diffusion method. Muller Hinton Agar was prepared and autoclaved for 15-20 min and poured in Petri plates and then cooled. The different concentrations (200, 400 , and $600 \mathrm{mg} / \mathrm{ml}$ ) of extract and fractions were used for this study. The Petri plates were kept for 3-4 h at low temperature and incubated at $36-37^{\circ} \mathrm{C}$ for $24 \mathrm{~h}$. Antibacterial activity was recorded by measurement of the zone of inhibition around each disc in the plate using zone reader. Dimethyl sulfoxide was used as negative control, and standard antibiotic Kalmicetine (chloramphenicol) was used as positive control. Each assay was used triplicate for determination of antibacterial test [11]. 
Table 1: Phytochemical screening result of karamunting leaf extract and fractions

\begin{tabular}{llll}
\hline Screening & Ethanolic extract & $\begin{array}{l}\text { Hexane } \\
\text { fraction }\end{array}$ & $\begin{array}{l}\text { Ethyl acetate } \\
\text { fraction }\end{array}$ \\
\hline Alkaloids & - & - & - \\
Flavonoids & + & - & + \\
Glycosides & + & - & + \\
Tannins & + & - & + \\
Saponins & + & - & + \\
Triterpenoid & + & + & - \\
Steroids & + & + & - \\
\hline
\end{tabular}

Table 2: Antibacterial activity of karamunting leaf extract and fractions

\begin{tabular}{lll}
\hline Samples & \multicolumn{2}{l}{ Zone of inhibition $(\mathrm{mm})$} \\
\cline { 2 - 3 } & \multicolumn{1}{l}{ S. aureus } & P. aeruginosa \\
\hline Ethanolic extract $(\mathrm{mg} / \mathrm{ml})$ & $12.56 \pm 0.75$ & $14.56 \pm 0.14$ \\
200 & $13.46 \pm 0.18$ & $15.4 \pm 0.3$ \\
400 & $14.5 \pm 0.14$ & $16.13 \pm 0.48$ \\
$\quad$ & & \\
Hexane fraction & $17.8 \pm 0.14$ & $18.3 \pm 0.25$ \\
200 & $19.23 \pm 0.27$ & $15.8 \pm 0.38$ \\
400 & $20.13 \pm 0.25$ & $14.8 \pm 0.07$ \\
600 & & \\
Ethyl acetate fraction & $17.75 \pm 0.27$ & $15.73 \pm 0.25$ \\
200 & $20.76 \pm 0.75$ & $19.23 \pm 0.25$ \\
400 & $21.5 \pm 0.75$ & $21.43 \pm 0.24$ \\
600 & $32.96 \pm 0.27$ & $32.8 \pm 0.67$ \\
Kalmicetine (chloramphenicol) & 0 & 0 \\
DMSO &
\end{tabular}

S. aureus: Staphylococcus aureus, P. aeruginosa: Pseudomonas aeruginosa, DMSO: Dimethyl sulfoxide

\section{RESULTS}

\section{Phytochemical screening}

Screening results of various extracts and fractions of karamunting leaf showed different chemical compound in different organic solvents.

\section{Antibacterial evaluation}

Antibacterial testing was done by agar diffusion method. The zone of inhibition was summarized in Table 1.

\section{DISCUSSION}

Karamunting leaves were analyzed for phytochemical composition such as alkaloids, flavonoids, and tannins. The phytochemical screening of crude ethanolic extract, hexane fraction, and ethyl acetate fraction of powdered karamunting leaf recorded very high values for flavonoids and tannins in ethanolic and ethyl acetate fraction. The high values that recorded for the plant extract showed that the powdered karamunting leaf maybe a good source of antimicrobial, especially as an antibacterial agent.

Historically, karamunting leaf has been used by Sipoholon district society against high bacterial infections, especially a skin infection such as acne and wound. In this study, karamunting shows effective against both Gram-positive and negative bacterial strains. Antibacterial activity of different extract and fractions (ethanolic extract, hexane fraction, and ethyl acetate fraction) of karamunting leaf were tested against $S$. aureus and P. aeruginosa. According to the result, all of the extract and fractions showed an inhibitory effect against both of these bacteria. It was observed that ethyl acetate fraction showed the most effective against $S$. aureus and $P$. aeruginosa.

This higher inhibition zone of the ethyl acetate fraction of karamunting leaf showed the effect of flavonoid and tannin compounds [17-19], which are known to have antimicrobial activity. This extract, therefore, may provide a lead for an antibiotic for this pathogen, and the extract itself may be recommended for topical application. In general, less polar fractions were better antimicrobial agents than their more polar counterparts. The mechanism of phenol compounds as antibacterial by denaturing proteins and damaging the lipids on the plasma membrane of microorganisms, thus causing the content of cells coming out [20]. Further investigation into this fraction has great prospects for future antibacterial drugs.

\section{CONCLUSIONS}

Karamunting leaf showed a good potential antibacterial agent against $S$. aureus and $P$. aeruginosa. The most active fraction of antibacterial activity was ethyl acetate fraction. The phytochemical results of ethyl acetate also contain a lot of phytochemical compounds especially flavonoids and tannins. The present study supports that; this plant can be used to discover bioactive natural products that may lead to the development of new drugs for bacterial inhibition especially to treat the topical skin diseases.

\section{ACKNOWLEDGMENTS}

The authors wish to thank Iksen, S.Farm., M.Si., for the support and providing the research work and publication.

\section{AUTHORS CONTRIBUTION}

All authors have equal contribution in bringing out this article.

\section{CONFLICT OF INTEREST}

None.

\section{REFERENCES}

1. Oyebode JA, Fajilade TO. Antibacterial activities of aquesous and ethanolic extract of Allium cepa (onion bulb) against some selected pathogenic microorganisms. Int J Sci Res Publication 2014;4:1-3.

2. Su PW, Yang CH, Yang JF, Su PY, Chuang LY. Antibacterial activities and antibacterial mechanism of Polygonum cuspidatum extracts against nosocomial drug-resistant pathogens. Molecules 2015;20:11119-30.

3. Saising J, Ongsakul M, Voravuthikunchai SP. Rhodomyrtus tomentosa (Aiton) hassk. Ethanol extract and rhodomyrtone: A potential strategy for the treatment of biofilm-forming staphylococci. J Med Microbiol 2011;60:1793-800

4. Hamid HA, Mutazah SS, Yusoff MM. Rhodomyrtus tomentosa: A phytocemical and pharmacology review. Asian J Pharm Clin Res 2017;10:10-6.

5. Limsuwan S, Hesseling-Meinders A, Voravuthikunchai SP, van Dijl JM, Kayser O. Potential antibiotic and anti-infective effects of rhodomyrtone from Rhodomyrtus tomentosa (Aiton) hassk. On Streptococcus pyogenes as revealed by proteomics. Phytomedicine 2011;18:934-40

6. Limsuwan S, Trip EN, Kouwen TR, Piersma S, Hiranrat A, Mahabusarakam W, et al. Rhodomyrtone: A new candidate as natural antibacterial drug from Rhodomyrtus tomentosa. Phytomedicine 2009; 16:645-51

7. Jeenkeawpieam J, Phongpaichit S, Rukachaisirikul V, Sakayaroj J. Antifungal activity and molecular identification of endophytic fungi from the angiosperm Rhodomyrtus tomentosa. Afr J Biotechnol 2012;11:14007-16.

8. Wu P, Ma G, Li N, Deng Q, Yin Y, Huang R, et al. Investigation of in vitro and in vivo antioxidant activities of flavonoids rich extract from the berries of Rhodomyrtus tomentosa (Ait.) hassk. Food Chem 2015; 173:194-202.

9. Tung NH, Ding Y, Choi EM, Van Kiem P, Van Minh C, Kim YH, et al. New anthracene glycosides from Rhodomyrtus tomentosa stimulate osteoblastic differentiation of MC3T3-E1 cells. Arch Pharm Res 2009;32:515-20

10. Jeong D, Yang WS, Yang Y, Nam G, Kim JH, Yoon DH, et al. In vitro and in vivo anti-inflammatory effect of Rhodomyrtus tomentosa methanol extract. J Ethnopharmacol 2013;146:205-13.

11. Sinulingga SE. Angiogenesis Effect of Ethyl Acetate Fraction Ointment 
of Karamunting Leaves on Rat Wound that Infected by Bacteria. Thesis, Faculty of Pharmacy, University of Sumatera Utara; 2017. p. 1-72.

12. Ahmed D, Saeed R, Shakeel N, Fatima K, Arshad A. Antimicrobial activities of methanolic extract of Carissa opaca roots and its fractions and compounds isolated from the most active ethyl acetate fraction. Asian Pac J Trop Biomed 2015;5:541-5.

13. Depkes RI. Materia Medika. Vol. 6. Jakarta: Ditjen POM; 1995. p. 297-307.

14. Farnsworth NR. Biologycal and phytochemical screening of plants. J Pharm Sci 1996;55:225-76.

15. Harbone JB. Metode Fitokimia. Vol. 2. Bandung: ITB; 1987. p. 6, 49.

16. Princely S, Dhanaraju MD. Assesment of phytochemical constituents, in vitro antimicrobial and antioxidant of ulva extracts from Vishakhapatnam coast. Asian J Pharm Clin Res 2017;10:87-95.

17. Robinson T. The Organic Constituent of High Plant. $4^{\text {th }}$ ed. New York: University of Massachusetts; 1995.

18. Aguado MI, Dudik NG, Zamora CM, Torres CA, Nunez MB. Antioxidant and antibacterial activities of hydroalcoholic extracts from Aloysia polystachya griseb moldenke and Lippia turbinata Griseb (Verbenaceae). Int J Pharm Pharm Sci 2016;8:393-5.

19. Shetty VG, Patil MG, Dound AS. Evaluation of phytochemical and antibacterial properties of Calotropis procera (Ait) R. Br. Leaves. Int J Pharm Pharm Sci 2015;7:316-9.

20. Pratiwi ST. Mikrobiologi Farmasi. Jakarta: Erlangga; 2008. 